\title{
Information Communication Technology (ICT) and Bank Performance Before and During COVID-19: Empirical Evidence of Nigeria
}

\author{
J.A Obadeyi ${ }^{1}$ \\ Department of Accounting \& Finance, Faculty of Humanities, Social \& Management Sciences, Elizade \\ University, Ilara-Mokin, Ondo State \\ Wole Adamolekun ${ }^{2}$ \\ Department of Mass Communication, Faculty of Humanities, Social \& Management Sciences, Elizade \\ University, Ilara-Mokin, Ondo State \\ A.A Akande ${ }^{3}$ \\ Department of Accounting \& Finance, Faculty of Humanities, Social \& Management Sciences, Elizade \\ University, Ilara-Mokin, Ondo State
}

ADEDIPE Oluwaseyi Ayodele ${ }^{4}$

Department of Accounting \& Finance, Faculty of Management Sciences, Ajayi Crowther University, Oyo, Oyo State

Corresponding email: georgefavour09@gmail.com

\section{Acknowledgement}

We appreciate Mr. Afolabi Kehinde Victor, Formerly, Banking Supervision Department, Central Bank of Nigeria (CBN) for helpful comments.

\begin{abstract}
This study assessed Information Communication Technology (ICT) and bank performance before and during COVID-19: Empirical evidence of Nigeria. The urgent need for ICT in banking subsector was unavoidable in Nigeria to meet daily liquidity needs and ease business transactions. Panel data comprised pooled Least Square (PLS), Fixed Effects Model (FEM) and Random Effects Model (RAM), which were adopted for a period of ten (10) years $(2011-2020)$. The choice of adopting the appropriate model could be traced to Hauman test outcome. The secondary source of data was from financial statements of thirteen (13) purposively sampled banks. Findings showed a mixed marginal influence of ICT on bank performance in Nigeria and were statistically significant. The study concluded that banks' financial products / services were fully supported and driven more by information communication-technology before and during recent temporary lockdown in Nigeria. The paper recommended that regulators and policymakers should review and implement information-technology vis-à-vis Fin-Tech policies as incomparable mechanism to improve bank performance in case of any uncertainties in the nearest future.
\end{abstract}

Keywords: Information Communication Technology, Bank Performance, COVID-19, Return on assets, Nigeria.

JEL Classification: C1, C23, C83, G2, O17

DOI: $10.7176 / \mathrm{IKM} / 11-4-13$

Publication date:October $31^{\text {st }} 2021$

\section{Introduction}

Financial and business environments are strongly and completely moving along the spectrum of dynamism globally due to innovation, creativity, and technological changes to satisfy the needs of customers. The adoption and use of information technology and information systems utilization started in the '70s (Momani, Jamous and Hilles, 2017). The relevance of ICT was not only felt on bank performance but on every economic agent. Recently, Nigerian economy faced recession in 2019 and the coronavirus outbreak (COVID-19)'s effect partially truncated Nigeria economy in the beginning of second quarter (Q2) of year 2020, thereby forcing it to another economic recession.

To have integrated financial year 2020 in this study showed that industries, governments, and families felt the consequence of pandemic massively. During this period, all sectors adopted IT platforms to transact business, 
schools at all levels used e-learning as a means of teaching, shops, supermarkets, malls, investors, and entrepreneurs were trading online. Since it was a global issue, the banking subsector was not an exception. Meanwhile, the banking subsector has continuously be operating in an unpredictable and competitive environment. The unpredictable circumstance was further threatened and triggered by the virus outbreak, whose effect had dwindled the profits and earnings of banks. The adverse effect of the pandemic resulted in winding up of companies, massive job losses, millions of people were confirmed to be infected, recovered and others eventually died, informal and formal precincts experienced losses and shortages, production lines were shutdown, global food shortages were experienced, and all forms of sporting events were suspended and cancelled including the Olympic Games scheduled to hold in Japan 2020.

Since the role of ICT could not be over-emphasized, the ICT phenomena adopted in the financial sector in providing electronic-banking services prevented the banking sector from total collapse.

The processing, diversifying and managing information with scientific and technological approaches have resulted increased adoption and utilisation of information communication technology (ICT) or otherwise known as information-tech. The information-tech was as a result of information explosion that enabled banks to survive during economic and financial crisis that bedevilled the financial markets, banks and non-bank financial institutions in the world in early 2007 to late 2008. But it was good to note that information has always played significant roles in scientific and technological development in speed, security, convenience and now as a means of survival. The success achieved in the performance of banks over the years could easily be traced to the emergence of ICT. Thus, Adamolekun's (1993) suggestion that rapid development and use of ICT in banks has transformed their products and services for the benefit of their customers.

ICT has a significant influence on individuals/households, firms, and governments on lives of the people, the way firms are able to generate revenues, ease process of channelling funds from surplus to deficit units (financial intermediations) and promoting economic stimulations for the country at large matters a lot. There were studies (Ikechukwu, 2000; Agboola, 2006; Dauda, 2010; Basweti, Masese and Martin, 2013; Isizoh, et al, 2013; Balogun, 2016; Kabiru, Mohd and Norlena, 2015; Bahrini and Qaffas, 2019) were on ICT and bank performance. But all have not thoroughly assessed in-depth relationship between ICT and performance of banks amid the virus outbreak. This gap motivated us to carry out this research in this area.

This study is the first to examine empirically the extent of interactions between ICT and bank performance before and during the coronavirus outbreak (COVID-9) in Nigeria. The study investigated thirteen (13) Deposit Money Banks (DMBs) in Nigeria. These DMBs were in composition of old and new generation banks. The study believed that 2005 financial reform and partial reform in 2009 have strengthened the financial capacity of these institutions to be mega banks. The research would contribute to the relevance of ICT to create enabling electronic platforms for business and financial transaction in a familiar and unfamiliar economic terrain and provide evidence on variable interconnections. This remained the maiden study that used pooled Least Square, Fixed Effects Model and Radom Effects Model thoroughly to analyse the data.

The other parts of this paper included literature review section, which focused on conceptual clarification of ICT and bank performance; while methodology section captured source of data and models for analysis, followed by results and discussion section, that explained and interpreted variables outcomes and the last section explored conclusion, policy implications and necessary recommendations.

\section{Literature Review}

\subsection{Concept of Information Communication Technology and Bank Performance}

Information and Communication Technology (ICT) involved the management of information electronically (Kajogbola, 2004; Acha, 2008; Isizoh, Anazia, Okide and Okwaraoka, 2013; Bahrini and Qaffas, 2019). For more than two decades, ICT has tremendously transformed the Nigerian market into information-tech driven society; and has compelled banks to collaborate with network operators and Nigerian Communication Commission (NCC) to upgrade mobile phones, broad bands and internet applications for efficient service delivery. This is because lack of information accessibility remains a challenge in Nigeria.

The late 1980s and early 1990s witnessed the proliferation of computers and internet applications which assisted the electronic banking services mostly in developed countries (Shapiro, 1999; Polasik and Wisniewski, 2008). ICT has positively affected banks by creating process for customers to access accounts, make payments and funds transfers easily and conveniently. The queuing of customers waiting to be attended to in the banking hall has since disappeared because with help of ICT customers could transact business in any part of the world without actually approaching the banks. 
The transformation experienced in different sectors was because of modern technological innovations, thereby allowing customers access financial services at all times. Some of the ICT channels for providing financial services and making payments included Automated Teller Machines (ATMs), internet banking, Point of Sale (POS), Credit and Debit Cards for deposits and making payments. Others are satellites, mobile phones, mobile cellular/wireless phones (World Bank, 2017).

The banking subsector has created tremendous investments opportunities in ICT to maintain infrastructure to make available modern electronic information services to customers and manage risk positions and pricing. ICT facilitated bank networking among branches and corresponding institutions internationally. The computerization and inter-connection processes have successfully unified banks regardless of geographical locations globally via Wide Area Network (WAN) mainly to consolidate customers' information. ICT has also created financial environment for self-service(s), such that prospective bank customers could quickly and easily complete bank transactions (e.g. opening of new accounts and validation of account numbers and make enquiries on online services).

It must be noted that all ICT products have assisted government in achieving its cashless policy in Nigeria. Some of the ICT products mostly used by bank customers include but not limited to:

\section{i. Automated Teller Machines (ATMs)}

The ATMs are simply the combination of terminals of computer software, record-system and cash vault, which allowed bank customers to access its book keeping system with a plastic card with inscribed Personal Identification Number (PIN) at any time of the day provided there is power supply and stable internet connection. The ATM could be used to withdraw and make payment either by cash or cashless methods as long as customers' time were preserved. According to Adeniran and Junaidu, (2014), some bank customers derive satisfaction for using ATM services due to the ease and quick means of accessing money, but dissatisfied with improper way of dispensing cash.

\section{ii. Telephone Banking}

More than one hundred and sixty million $(160,000,000)$ Nigerians use phones. This ICT product permitted every bank customer to engage in banking transaction(s) via a phone. The telephone banking services ensured customers' convenience during transaction. This transaction also depended strictly on the availability of active phone cells and good network, while internet accessibility could be optional. Telephone banking is one the ways of promoting retail banking services to customers during and outside banking hours. Telephone banking is one of the routes of carrying out banks' financial services (Ahmad and Buttle, 2002).

\section{iii. Point of Sale (POS)}

It used as an on-line platform system which easily permit customers to transfer money instantaneously between one bank account to another. POS has made business and financial transactions possible and has ameliorated the challenges customers experience in making payment or withdraw cash from the banking hall. A debit card could be more associated with POS often through the activation of an electronically fund transfer procedure - process; in addition, bank customers needed not get to banking premises before transactions could be completed. POS means of transaction has gradually started in Nigeria outside banking sector since there are more funds outside banking industry. With POS, withdrawal and payment could take place at any time of the day (24/7). According to Sai (2017), POS has dramatically helped to improve efficiency, transparency, answerability, and security evaluations.

\subsubsection{Return on Asset (ROA)}

One of the methods that measured bank performance was through return on asset (ROA). Return on Asset (ROA) helped to measure the company's capability to make profits relative to its assets (Chandra, 2005). A higher ROA was an indication of an increase in the company's earnings realized through the efficient use of company's total assets over a particular period. Consequently, it reflected the profitability of banks before leverage, which estimated the amount of bank profits that would be made per naira of its assets. ROA showed how well a bank was managing its assets to optimize its profitability. The ratio included return on the portfolio and revenues generated from investments and other operating activities.

\subsubsection{Brief History of Corona Virus Disease (COVID-19)}

Corona Virus Disease (COVID-19) was a virus that is linked with other categories of viruses most especially with Severe Acute Respiratory Syndrome (SARS), the virus which caused COVID-19. It was learnt that first human case of the virus, was caused by novel coronavirus causing COVID-19, which was later identified as SARS-CoV- 
2. Reports showed that the first outbreak was from a food market in Wuhan, China, 2019. This led to the closure of the market a month after. COVID-19 was discovered not to have its origin from laboratory manipulations but was naturally traced to animal (bat) origin. The pandemic outbreak started from china and spread to all parts of the world (World Health Organisation, 2020).

We therefore believe that the effect of the COVID-19 has caused collateral damage not only in Nigeria, but globally; and there is no hiding place for the banking subsector either. But ICT in all ramifications has protected the banking sector that was driven by information-tech from either total collapse or permanent extinction.

\subsection{Technology Acceptance Theory}

The technology acceptance theory was propounded by Davies in 1986. The Technology Acceptance was an information systems theory that assisted how users come to accept and use a technology in form of a model. The theory could further be extended to reasoned action for the main purpose of illustrating and forecasting information communication technology behavioural usage and performance. Technology acceptance theory emphasized the attitudinal prediction channel towards the usage of the system. Though, the technological acceptability's determining factors helped to evaluate 'perceived usefulness' - explained extent to which a system was relied and believed on by user(s) to promote performance and 'perceived ease' - showed system user(s) obvious reason not to be involved in an effort for using the system / information technology (Davis, 1986 and 1989). However, since the theory was in form of a model; some stages were allowed to revolve in its development. Firstly, adoption stage: This stage led to test and use of model development via information and system applications; secondly, validation stage, this stage captured accurate / correct user's measurement and lastly, extension stage; this stage explained the introduction of new related variables. Consequently, extension stage resulted to Extended Technology Acceptance Model that was further developed by Venkatesh and Davis in 2000 to meet perceived use and ease in cognitive influence view. But the social view was more related to organizational results, job performance and management relevance (Venkatesh and Davis, 2000; Venkatesh, Morris, Davis and Davis, 2003).

\subsection{Empirical Review}

Adeniran and Junaidu (2014) identified factors that affected the utility of customers' towards the use and ease of system in Nigeria. They postulated that ATM improved banking services. This was because funds could easily be accessed by customers during or outside banking hours. Adeniran and Junaidu, (2014) empirically studied automated teller machine (ATM) and user satisfaction in Nigeria, a study of United Bank for Africa in Sokoto metropolis. They explained that ATM helped to prevent unnecessary queues in banking halls and customers were able to have access to funds conveniently.

World Bank Group (2006) studied the impact of information and communications technology on enterprises. The result showed that ICT had great influence on labour productivity capacity most especially in business enterprises due to information technology. Wu (2006) studied the impact of information technology on firm performance and adopted both Data Envelopment Analysis (DEA) and Decision Trees (DTs). The study concluded that there was a positive relationship and strong influence on variables. Ahmad and Buttle (2002) examined retaining telephone banking customers at Frontier Bank in United Kingdom. It was believed that customers' preference for telephone banking led to its adoption as one of the financial services of the bank. Sai (2017) analysed point of sale systems physical configurations and security measures in Zimbabwean SMEs. He claimed that POS systems has indirectly exposed banks to genuineness of data and problem of security.

Eze and Akujuobi (2009) examined ICT and bank performance, a case of Nigerian commercial banks. The scope of their study was between 1970 and 2008, t-ratio analysis was used and findings showed that ICT had a favourable influence on banks' performance.

Muhammad, Gatawa and Kebbi (2013) examined the impact of ICT on bank performance, a study of selected commercial banks in Nigeria. The study covered a period 2001 to 2011, and analysed data through Fixed and Random Effects Models. Findings showed that ATM did not enhance banks performance. Binuyo and Aregbesola (2017) assessed the impact of ICT on commercial bank performance, evidence from South Africa for a period 1990 - 2012. The dynamic panel environment through the use of orthogonal transformation technique was used to analyse the data. The study concluded that ICT cost efficiency and investment contributed to bank performance. Acharya, Kagan, Lingam and Gray, (2008) studied impact of website usability on performance: A heuristic evaluation of community bank homepage implementation and found that banks which adopted ICT platforms in operations greatly performed than other banks with less ICT inclination.

This study regarded the virus as an outbreak in Nigeria but not as pandemic considering number of infections, recoveries and mortality rates compared to other countries such as South Africa, United States, Italy, India and 
United Kingdom. In lieu of this, the COVID-19 outbreak was adopted as an intervening variable between the criterion and predictor variables interactions as depicted in the conceptual model.

\subsection{Conceptual Framework}

\section{Dependent Variable Independent Variables}

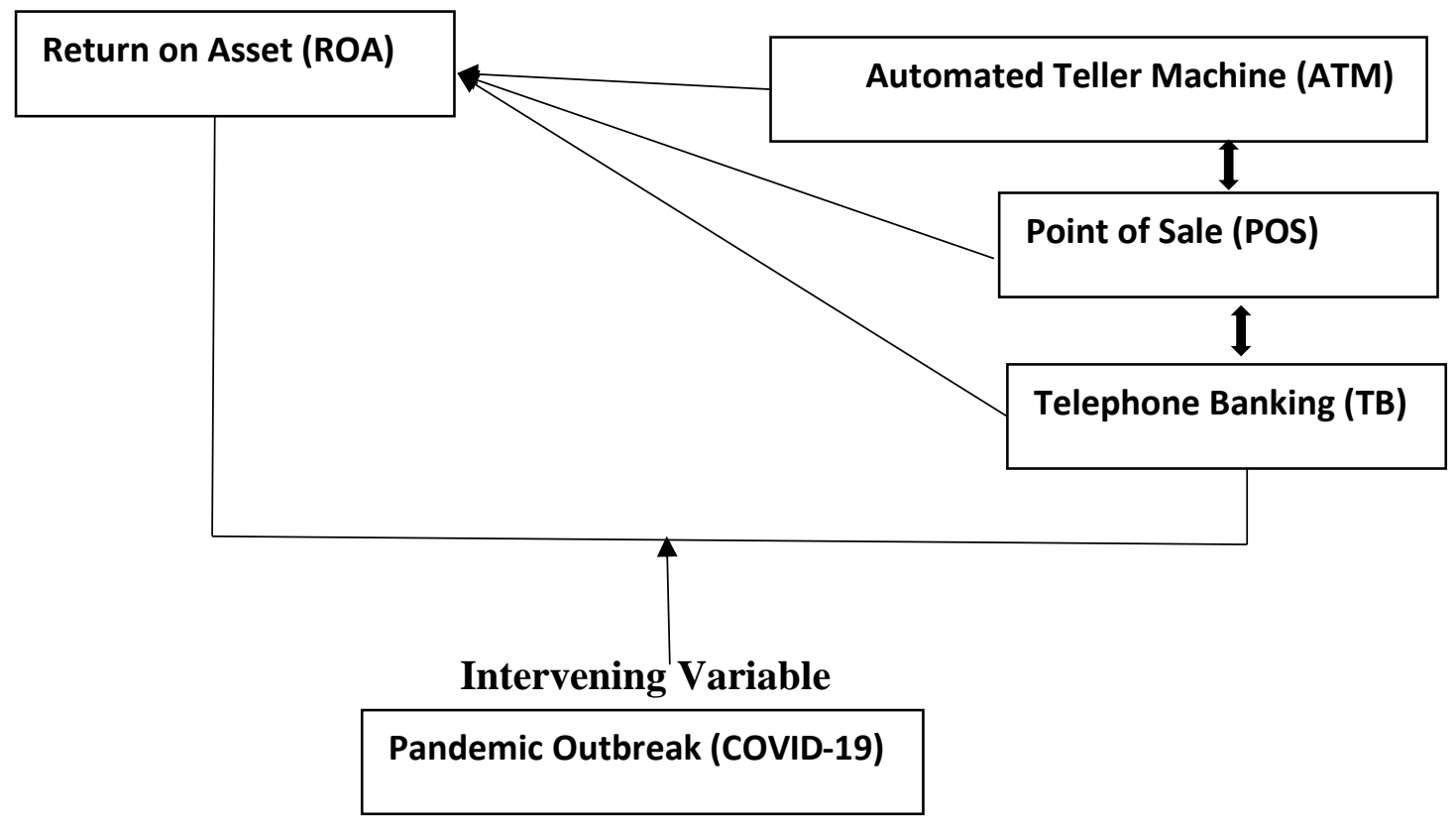

Fig. 1: Conceptual Model of ICT influence on Bank Performance amid COVID-19. Source: Authors' Compilation, (2021)

\section{Methodology}

The study assessed financial statements of thirteen (13) purposively selected banks for 2011 - 2020. This period marked the aftermath of global financial and economic crunch and Nigerian banking sector has remained healthy and competitive ever since. But recently, the present effect of virus outbreak has led to decline in price of crude oil and the country's foreign reserves. A panel data was analysed with E-Views econometric software version 9. Panel data combined both cross - section and time series; and assumed regressors to be non-stochastic. The Pooled Least Square (PLS), fixed effects (FE) and random effects (RE) models characterized the panel data model and how time-constant heteroskedasticity problem could be resolved (Yaffee, 2005; Baltagi, 2005, Gujarati, 2013).

The best underlying assumptions that were appropriate for theories and data determined researchers' approach to a study (Raffalovich, and Chung, 2014). ICT was the predictor variables measured by Automated Teller Machine (ATM), Point of Sale (POS) and Telephone Banking; and bank performance was the criterion variable measured by Return on Asset (ROA).

The Pooled Least Square model was stated thus:

$\mathrm{Y}_{\mathrm{it}}=\delta_{1}+\delta_{2} \mathrm{X}_{\mathrm{it}}+\omega_{\mathrm{it}}$

Where

Where i equal to ith subject and t equal to time period for the variables

$$
\begin{aligned}
& \delta_{1}=\text { the intercept; } \delta_{2} \text { was the coefficient; } X \text { was the regressor variable } \\
& \omega=\text { disturbance or error term; } Y=\text { dependable variable }
\end{aligned}
$$

The fixed effects model (FEM) assumed that differences that existed between individual cross-sections were accommodated from varieties of intercepts. FE accepted that cross-sections and time periods could be different in many unspecified ways (unobserved variable bias). But in pooled data model, the outcome could be regarded as unequal variances (heteroskedasticity). FE absorbed these deviations from randomness by integrating a dummy variable for every cross-section and every time period (Raffalovich, and Chung, 2014). FEM's assumption of a 
model allowed constant intercept for every cross section with an unrealistic time. The FEM also employed OLS and stated thus:

$$
\mathrm{Y}_{\mathrm{it}}=\delta_{1 \mathrm{i}}+\delta_{2} \mathrm{X}_{\mathrm{it}}+\omega_{\mathrm{it}}
$$

The equation (ii) illustrated that the 'fixed effects' occurred due to intercepts differences across all subjects and each entity remained constant over time that is, $\delta_{1 \mathrm{i}}$. Therefore, coefficients of the predictor variables were constant across subjects (Greene, 2008; Gujarati, 2013).

The REM permitted differences between intercepts to be accepted by error terms of individual subject. REM also has the ability of eliminating heteroscedasticity. Hence, REM equation random was:

$$
\mathrm{Y}_{\mathrm{it}}=\delta_{1 \mathrm{i}}+\delta_{2} \mathrm{X}_{\mathrm{it}}+\omega_{\mathrm{it}}
$$

From equation (iii), $\delta_{1 \mathrm{i}}$ was not identified as fixed but assumed as random with value of mean as $\delta_{1}$, which didi not have a subscript i). However, value of an intercept for every bank would be stated as;

$$
\delta_{1 \mathrm{i}}=\delta_{1}+\mathrm{u}_{\mathrm{i}}
$$

Gujarati (2013) claimed that $u_{i}$ was random disturbance term, whose mean value assumed to be zero and with variance of $\sigma \mathrm{u}^{2}$. The thirteen banks were drawn from larger population sample of DMBs with intercept value of $\delta_{1}$. Each difference that characterized intercept value of each bank was identified in the disturbance $\left(u_{i}\right)$. To substitute equation (iv) in equation (iii); we obtained

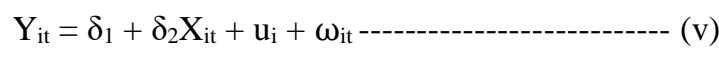

The equation (v) was re-written as

$$
\begin{aligned}
& \mathrm{Y}_{\mathrm{it}}=\delta_{1}+\delta_{2} \mathrm{X}_{\mathrm{it}}+v_{\mathrm{it}}--------------------------(v i) \\
& \text { But } \quad v_{i t}=u_{i}+\omega_{i t}------------------------(v i i)
\end{aligned}
$$

Where $v_{i t}$ could be regarded as composite error term that captured both $u_{i}$ and $\omega_{i t}$.

$\mathrm{u}_{\mathrm{i}}=$ cross-section or error component and $\omega_{\mathrm{it}}$ combined cross section error components and time series with time and subject variations. The REM depicted that composite disturbance term involved;

$$
\begin{gathered}
u_{i} \sim N\left(0, \sigma^{2} u\right) \\
\omega_{i t} \sim N\left(0, \sigma^{2} \omega\right) \\
E\left(u_{i} \omega_{i t}\right)=0 ; E\left(u_{i} u_{i j}\right)=0 ;(i \neq j) \\
E\left(\omega_{i} \omega_{i s}\right)=E\left(\omega_{i j} \omega_{j s}\right)=E\left(\omega_{i t} \omega_{i s}\right)=0 ;(i \neq j ; t \neq s)
\end{gathered}
$$

The equation (viii) illustrated that individual specific error components were unable to correlate with one another. Thus, $v_{\text {it }}$ wa s uncorrelated with any of the predictor variables in the model. Therefore, if this occurred, REM result could be stated to be an inconsistent estimation parameter. But with the help of Hausman test, it would assist to determine if $v_{\text {it }}$ was correlated with the explanatory variables that is, determining whether REM was appropriate or not). Recall, disturbance component was indirectly observed. Furthermore, having examined equation (viii) assumption, it would be stated thus;

$$
\begin{aligned}
E\left(v_{i t}\right) & =0 \\
\operatorname{var}\left(v_{i t}\right) & =\sigma^{2} u+\sigma^{2} \omega-1(x)
\end{aligned}
$$

Suppose $\sigma^{2} u$ was equal to zero, this meant that there was similarity between (i) and (v) equations. This would allow time series observations and cross sectional observations be pooled and run together with regression as reflected in equation (i). The disturbance or error term would be homoscedastic as indicated in equation (xi).

For the purpose of this study, the predictor variables were expressed in terms of Automated Teller Machine (ATM), Point of Sale (POS) and Telephone Banking services, which influenced the dependent variable that was expressed by Return on Asset (ROA). The OLS model adopted was restated as;

$$
\mathrm{Y}_{\mathrm{it}}=\delta_{1}+\delta_{2} \mathrm{X}_{\mathrm{it}}+\omega_{\mathrm{it}}
$$

Therefore, equation (vi) would be re-written as

$\mathrm{ROA}_{\mathrm{it}}=\delta_{1}+\delta_{2} \mathrm{ATM}_{\mathrm{it}}+\delta_{3} \mathrm{POS}_{\mathrm{it}}+\delta_{4} \mathrm{~TB}_{\mathrm{it}}+\omega_{\mathrm{it}}$ 


\subsection{Measurement of Variables}

All variables expressed in the model were measured as:

Dependent Variable: Return on Asset depicted how well a financial institution managed its assets optimally to realize profit.

Independent Variable: These were the predictor variables in the equation. The ATMs were simply combination of terminals of computer software, record-system and cash vault that permitted customers to access its book keeping system with a plastic card. POS was an on-line platform service system that allowed bank customers to make fund transfer instantaneously between a bank account to another but not only at a purchased centres and telephone banking (TB) permitted every customer to engage in banking transaction(s) via a phone. Apriori was estimation coefficients of variables expected to be $\delta_{2}>0 ; \delta_{3}<0$; and $\delta_{4}>0$. Summarily, there was a direct and positive influences.

\section{Hausman Test for Appropriate Model}

To select the appropriate model for the study, the choice would be bestowed on the Hausman test result. Hausman test propositions stated that Ho: Choose REM $(p>0.05)$ and Hi: Choose FEM $(p<0.05)$. The test result eventually skewed towards REM. Therefore, REM would be adopted for the study.

\section{Result and Discussion}

\subsubsection{Descriptive Statistics of Study Variables}

The table 4.1.1 depicted summary of descriptive statistics for variables such that the mean and standard deviation (S.D) for ATM, POS, TB and ROA were mean (16.370), S.D (1.745810); mean (18.214), S.D (2.11328); mean (14.26), S.D (1.210642) and mean (2.879747); S.D (2.358576) respectively. The maximum and minimum values for ATM, POS, TB and ROA were max (19.5000), $\min$ (12.25000); $\max$ (205.000), min (165.0000); max (14.2100), $\min (7.15200)$ and $\max (12.2400)$, $\min (1.050000)$ respectively. The Jarque Bera values expressed ATM (2.498301), POS (1.16678); TB (3.697305) and ROA (5.7688). The observation was 130 . The probability values of Jarque Bera variables were greater than 0.05 , therefore, residuals were normally distributed.

Table 4.1.1: Descriptive Statistics Summary

\begin{tabular}{|l|l|l|l|l|l|l|l|}
\hline Variables & Mean & $\begin{array}{l}\text { Standard } \\
\text { Deviation }\end{array}$ & Maximum & Minimum & $\begin{array}{l}\text { Jargue- } \\
\text { Bera }\end{array}$ & Probability & Observation \\
\hline ATM & 16.370 & 1.745810 & 19.5000 & 12.25000 & 2.498301 & 0.286748 & 130 \\
\hline POS & 18.214 & 2.11328 & 205.000 & 165.0000 & 1.16678 & 0.071383 & 130 \\
\hline TB & 14.26 & 1.210642 & 14.2100 & 7.15200 & 3.697305 & 0.120147 & 130 \\
\hline ROA & 2.879747 & 2.358576 & 12.2400 & 1.050000 & 5.7688 & 0.350311 & 130 \\
\hline
\end{tabular}

Source: Authors' Compilation, 2021

\subsubsection{Panel Regression}

Table 4.1.1 depicted panel regression on the extent of ICT influenced variables on bank performance capturing PLS, FEM and REM. The PLS expressed a positive and negative marginal influence of ATM, POS and TB with coefficient values of (5.32), (-1.49) and (8.36) respectively on ROA. Variables were statistically significant $(\mathrm{p}<0.05)$. The combined ICT variables accounted for $0.573134(57.3 \%)$ of the variation in the ROA as shown by the $\mathrm{R}^{2}$ value. The remaining $22.7 \%$ variations were explained by other predictor variables. The Durbin Watson (DW) was 1.870246 . The closeness of DW to 2 approximately expressed no sign of autocorrelation.

The fixed effects model as shown in second column depicted that coefficients of predictor variables have mixed values with ATM (6.22), POS (-1.74) and TB (2.19). Variables were statistically significant $(\mathrm{p}<0.05) .0 .5416327$ 
(54\%) variations expressed in the value of ROA was accounted for by the ICT variables and remaining $46 \%$ variations would be explained by other explanatory variables.

The REM results also reflected marginal influence of ATM, POS and TB with coefficient values of (1.68), (2.13) and (7.01) respectively on ROA. For every ATM's ability to meet cash accessibility of customers and ability to make payment, the bank ROA's increases by 1.68, POS helped ROA to move up by 2.13 and TB by 7.01. Both ATM and TB were statistically significant at $\mathrm{p}<0.05$, while POS was statistically significant at $\mathrm{p}<0.1$. This showed an extent at which ICT has assisted banks to continue providing e-financial services before and during virus outbreak. Evaluating these transactions, there were bank charges on millions of customers' accounts on every transaction either through ATM, POS or TB. The multiplying impact would increase returns on asset of banks that were information -technology inclined. The combined ICT variables accounted for $0.511726(51.2 \%)$ of the variation in the ROA as shown by the $\mathrm{R}^{2}$ value. The remaining $48.8 \%$ variations was explained by other explanatory variables. The Durbin Watson (DW) was 1.931299. The closeness of DW to 2 approximately expressed no sign of autocorrelation.

Table 4.1.1: ICT variables impact on Bank performance (ROA).

\begin{tabular}{|c|c|c|c|}
\hline & ALL & ALL & ALL \\
\hline & PLS & FEM & REM \\
\hline ATM & $\begin{array}{l}5.32 \mathrm{E}-04 * * \\
(2.47 \mathrm{E}-04)\end{array}$ & $\begin{array}{l}6.22 \mathrm{E} .04 * * \\
(3.14 \mathrm{E}-03)\end{array}$ & $\begin{array}{l}1.68 \mathrm{E} .06 * * \\
(2.42 \mathrm{E}-06)\end{array}$ \\
\hline POS & $\begin{array}{l}-1.493201 * * \\
(0.132118)\end{array}$ & $\begin{array}{l}-1.74 * * \\
(1.236277)\end{array}$ & $\begin{array}{l}2.132641 * * * \\
(0.043231)\end{array}$ \\
\hline TB & $\begin{array}{l}8.360027 * * \\
(0.053364)\end{array}$ & $\begin{array}{l}2.191774 * * \\
(0.144569)\end{array}$ & $\begin{array}{l}7.012402 * * \\
(3.142552)\end{array}$ \\
\hline $\mathrm{C}$ & 2.173293 & 5.091431 & 0.491628 \\
\hline $\mathrm{R}^{2}$ & 0.573134 & 0.541632 & 0.511726 \\
\hline OBS. & 130 & 130 & 130 \\
\hline $\mathrm{N}$ & 13 & 13 & 13 \\
\hline
\end{tabular}

Source: Authors' Compilation, 2021

Note: Independent variables were differenced to ensure stationarity and thereby avoiding spurious regression while the dependent variable ROA was in log form. The level of significance was denoted as $* * * P<0.1$, **P< 0.05 and $* P<0.01$. Figure in the parentheses were (standard error).

\section{Findings}

i. Findings from the study showed positive values assigned to ATM, could be a result of many installed ATM machines across branches and nationwide to meet liquidity needs of customers either during banking hours or not. ii. Findings also showed that telephone banking result reflected that many bank customers have enjoyed banking services through the use of phones with charges on (e.g. voice calls, short message services, Unstructured Supplementary Service Data - USSD). The cumulative charges on telephone banking increased banks returns on asset considering large number of customers).

iii. Findings have also shown that every functioning POS enhanced quality service delivery and aid business and finance transactions, but due to insufficient number of POS outside the banking subsector particularly in the informal industry attracted less returns.

iv. All the variables in the study were statistically significant at $(0.05>\mathrm{p}<0.1)$.

v. Findings from PLS, FEM and REM averagely revealed that $\mathrm{R}^{2}=54.2 \%(0.542164)$. This depicted how ICT variables jointly explained the variations in ROA.

vi. The findings also showed that Pooled Least Square (PLS), Fixed Effects Model (FEM) and Random Effects Model (REM) results were similar. Therefore, REM result $\left(\mathrm{R}^{2}=51.2 \%\right)$ was adopted due to Hausman test outcome.

\subsection{Conclusion and Recommendations}

The study examined ICT and bank performance before and amid COVID-19 in Nigeria. ICT has increased bank profits, but it was good to understand that ROA could be proxy by profit. Since bank performance could be proxy 
by ROA. Therefore, from our findings, we concluded that ICT influenced bank performance. ICT has revolutionized business activities, interconnection and transaction. ICT has compelled banks and other financial institutions to influence quality of e-banking service delivery to improve customers' satisfaction. ICT has remained the bedrock of banks in terms of speed, convenience, and security to cope with banking market dynamism and unexpected shock caused by COVID-19 outbreak. To this end, there was need to put in place information-tech policies to enable banks achieve optimum performance and to mitigate network fluctuations problems.

\section{References}

Acha, I. A. (2008). Electronic banking in Nigeria: Concepts, challenges and prospects. International Journal of Development and Management Review, 3(1), 88-97.

Acharya, R. N., Kagan, A., Lingam, S. R., and Gray, K. (2008). Impact of website usability on performance: A heuristic evaluation of community bank homepage implementation. Journal of Business \& Economics Research (JBER), 6(6). https://doi.org/10.19030/jber.v6i6.2439

Adeniran, L. M., and Junaidu, A. S. (2014). An empirical study of automated teller machine (ATM) and user satisfaction in Nigeria: A study of United Bank for Africa in Sokoto metropolis. International Journal of Management Technology, 2(3), 1-11.

Agboola, A.A (2006). Electronic payment systems and tele-banking services in Nigeria. Journal of Internet Banking and commerce, 11(3), htt://www.arraydev.com/commerce/jibcl

Aghaei, M., and Rezagholizadeh, M. (2017). The Impact of information and communication technology (ICT) on economic growth in the OIC Countries. Economic and Environmental Studies, 17(2), 255-276.

Ahmad, R., and Buttle, F. (2002). Retaining telephone banking customers at frontier bank. International Journal of Bank Marketing, 20(1), 5 -16.

Bahrini, R., and Qaffas, A. (2019). Impact of information and communication technology on economic growth: Evidence from developing countries. Economies 7:21, 1 -13.

Baltagi, B.H (2005). Econometric analysis of panel data ( $3^{\text {rd }}$ ed.). England: Wiley and Son Ltd.

Binuyo, A.O., and Aregbesola, R.A (2017). The impact of information and communication technology (ICT) on commercial bank performance: Evidence from South-Africa. https://www.researchgate.net/publication/268979895

Bruderl, J. (2005). Panel data analysis. Retrieved from http://www.sowi.unimannheim.de/lihrstuehle/lessm/veranst/panelanalysepdf.

Chandra, P. (2005). Investment analysis and portfolio management (2nd ed.). New Delhi: Tata McGraw -Hill.

Davis, F. D. (1986). A technology acceptance model for empirical testing new end-user information system theory and results. Massachusetts Institute of Technology.

Davis, F. D. (1989). Perceived usefulness, perceived ease of use, and user acceptance of information technology. Management Information Systems Quarterly, 13(3), 319-340. doi:10.2307/249008

Eze, A.L., and Akujuobi, A.B.C (2009). Information and communication technology and bank performance: The case of Nigerian commercial banks. An International Multi-Disciplinary Journal, 3(5), 227 - 232.

Greene, W.H (2008). Econometric analysis (6 ${ }^{\text {th }}$ ed.). New York University: Stern School of Business.

Gujarati, D.N. (2013). Basic econometrics (5th ed.). Glasgow: McGraw-Hill Inc.

Ige, O. (1995). Information technology in deregulated telecommunications environment key note address, infotech 95. First International Conference on Information Technology Management, Lagos, Nov. 16-17.

Isizoh, A.N., Anazia, A.E., Okide S.O. and Okwaraoka, C.A.P (2013). Impacts of Information and communication technology in the Nigerian economy. International Journal of Engineering Research \& Technology 2(1), 1 -5. 
Kajogbola, D.O (2004). The impact of information technology on the Nigerian economy: A study of manufacturing and services sectors in the South-Western and South Eastern zones of Nigeria. ATPS Working Paper Series No. 39. Published by the African Technology Policy Studies Network, Nairobi, Kenya.

Momani, A.M., Jamous, M.M. and Hilles, M.S. (2017). Technology Acceptance theories: Review and classification. International Journal of Cyber Behavior, Psychology and Learning, 7 (2), 1 -12.

Muhammad, A., Gatawa, N.M. and Kebbi, H.S.B. (2013). Impact of information and communication technology on bank performance: A study of selected commercial banks in Nigeria. European Scientific Journal, 9(7), 213 219.

Pilat, D. (2002). OECD work on ICT and business performance - the role of data linking. 17th Voorburg Meeting on Service Statistics Nantes.

Polasik, M. and Wisniewski, T.P. (2008). Empirical analysis of internet banking adoption in Poland. International Journal of Bank Marketing, 27(1)32 - 52.

Raffalovich, L.E and Chung, R. (2014). Models for pooled time-series cross-section data. International Journal of Conflict and Violence, 8(1), $211-221$.

Sai, K. (2017). An analysis of point of sale systems physical configurations and security measures in Zimbabwean smes. IRA International Journal of Education and Multidisciplinary Studies 6(2), 181-190. doi:http://dx.doi.org/10.21013/jems.v6.n2.p5

Shapiro, J. (1999). Innovation in financial services case study: Home banking. MIT IPC Working Paper 99-004, Massachusetts Institute of Technology, Boston: MA, March.

Venkatesh, V. (2000). Determinants of perceived ease of use: Integrating control, intrinsic motivation, and emotion into the technology acceptance model. Information Systems Research, 11(4), $342-365$. doi:10.1287/isre.11.4.342.11872

Venkatesh, V., and Davis, F. D. (2000). A theoretical extension of the technology acceptance model: Four longitudinal field studies. Management Science, 46(2), 186-204. doi:10.1287/mnsc.46.2.186.11926

Venkatesh, V., Morris, M. G., Davis, G. B., and Davis, F. D. (2003). User acceptance of information technology: Toward a unified view. Management Information Systems Quarterly, 27(3), 425-478.

Weerasiri, R.A.S and Koththagoda, K.C (2017). The impact of automated teller machines (ATMs) service on customer satisfaction: A study based on State banks in Sri Lanka. Journal on Banking \& Insurance Research, 6(2), 2- 12 .

Wole Adamolekun (1993). Community banking system: Modernizing the informal financial intermediaries in Nigeria. Innovative Banking Monograph Series, 1: 8 - 30

World Bank Group (2006). Information and communications for development: Global trends and policies, Washington: Communications Technologies Department, 303.

World Health Organisation (2020). Coronavirus disease 2019 (COVID-19) Situation Report - 94. Data as received by WHO from national authorities by 10:00 CEST, 23 April 2020.

Wu, D. (2006). Detecting information technology on firm performance using DEA and decision trees. International Journal of Information Technology and Management 5(2), 162-174 http://porta.acm.org/citation.cfm?id

https://www.who.int/publications-detail/infection-prevention-and-control-during-health-care-when-novelcoronavirus-(ncov)-infection-is-suspected-20200125 


\section{APPENDIX}

\section{POOLED REGRESSION FOR ROA}

\section{POOLED REGRESSION FOR ROA AS DEPENDENT VARIABLE}

Dependent Variable: LOG(ROA?)

Method: Pooled Least Squares

Date: 1/10/21 Time: 13:21

Sample (adjusted): 20112020

Included observations: 10 after adjustments

Cross-sections included: 13

Total pool (balanced) observations: 130

\begin{tabular}{crlrl}
\hline \hline Variable & Coefficient & Std. Error & t-Statistic & Prob. \\
\hline \hline C & 2.173293 & 1.210891 & 1.794788 & 0.0000 \\
D(ATM?) & $5.32 \mathrm{E}-04$ & $2.47 \mathrm{E}-04$ & 1.139422 & 0.0000 \\
D(POS?) & -1.493201 & 0.132118 & -11.30203 & 0.0014 \\
D(TB?) & 8.360027 & 0.053364 & 156.66043 & 0.0000 \\
\hline \hline R-squared & 0.573134 & Mean dependent var & 5.346911 \\
Adjusted R-squared & 0.534381 & S.D. dependent var & 0.073288 \\
S.E. of regression & 2.043119 & Akaike info criterion & 4.214946 \\
Sum squared resid & 4034.012 & Schwarz criterion & 4.041032 \\
Log likelihood & 112.0126 & Hannan-Quinn criter. & 4.301173 \\
Durbin-Watson stat & 1.870246 & & \\
\hline \hline
\end{tabular}

\section{FIXED EFFECTS FOR (ROA)}

Dependent Variable: LOG(ROA?)

Method: Pooled Least Squares

Date: 1/10/21 Time: 12:31

Sample (adjusted): 20112020

Included observations: 10 after adjustments

Cross-sections included: 13

Total pool (balanced) observations: 130

\begin{tabular}{|c|c|c|c|c|}
\hline Variable & Coefficient & Std. Error & t-Statistic & Prob. \\
\hline $\mathrm{C}$ & 5.091431 & 1.130834 & 4.502368 & 0.0000 \\
\hline D(ATM?) & $6.22 \mathrm{E}-04$ & $3.14 \mathrm{E}-03$ & 1.980892 & 0.0443 \\
\hline $\mathrm{D}(\mathrm{POS} ?)$ & -1.740013 & 1.236277 & -1.407462 & 0.0297 \\
\hline $\mathrm{D}(\mathrm{TB} ?)$ & 2.191774 & 0.144569 & 15.160747 & 0.0431 \\
\hline \multicolumn{5}{|l|}{ Fixed Effects (Cross) } \\
\hline _ACCESS - C & 0.218844 & & & \\
\hline _FIDELITY_C & 1.524722 & & & \\
\hline _FCMB-C & -0.116775 & & & \\
\hline FBN-C & 0.428006 & & & \\
\hline - GTB $-\mathrm{C}$ & -0.303101 & & & \\
\hline _UNNION-C & -0.118113 & & & \\
\hline -UBA-C & -0.201254 & & & \\
\hline ZENITH-C & 0.173636 & & & \\
\hline _UNNITY-C & -0.214319 & & & \\
\hline _WEMA-C & 0.621121 & & & \\
\hline STERLING-C & 1.123418 & & & \\
\hline ECO $-\mathrm{C}$ & 0.301033 & & & \\
\hline \multicolumn{5}{|l|}{ STANBIC IBTC_- } \\
\hline $\mathrm{C}$ & -1.201347 & & & \\
\hline
\end{tabular}


Effects Specification

Cross-section fixed (dummy variables)

\begin{tabular}{lrll}
\hline \hline R-squared & 0.541632 & Mean dependent var & 8.262947 \\
Adjusted R-squared & 0.522017 & S.D. dependent var & 3.003933 \\
S.E. of regression & 2.141001 & Akaike info criterion & 5.150442 \\
Sum squared resid & 10.21973 & Schwarz criterion & 5.001175 \\
Log likelihood & -21.10469 & Hannan-Quinn criter. & 5.241386 \\
F-statistic & 11.21132 & Durbin-Watson stat & 1.634421 \\
Prob(F-statistic) & 0.000000 & & \\
\hline \hline
\end{tabular}

Source: E-View 9.0 Version

\section{RANDOM EFFECTS FOR ROA}

\section{Random effects}

Dependent Variable: LOG (ROA?)

Method: Pooled EGLS (Cross-section random effects)

Date: $1 / 10 / 21$ Time: 14:37

Sample (adjusted): 20112020

Included observations: 10 after adjustments

Cross-sections included: 13

Total pool (balanced) observations: 130

Swamy and Arora estimator of component variances

\begin{tabular}{|c|c|c|c|c|}
\hline Variable & Coefficient & Std. Error & t-Statistic & Prob. \\
\hline $\mathrm{C}$ & 0.491628 & 0.149783 & 3.282268 & 0.0003 \\
\hline D(ATM?) & $1.68 \mathrm{E}-06$ & $2.42 \mathrm{E}-06$ & 0.694215 & 0.0000 \\
\hline $\mathrm{D}(\operatorname{POS} ?)$ & 2.132641 & 0.043231 & 49.331290 & 0.0828 \\
\hline $\mathrm{D}(\mathrm{TB} ?)$ & 7.012402 & 3.142552 & 2.231435 & 0.0032 \\
\hline \multicolumn{5}{|l|}{ Random Effects (Cross) } \\
\hline _ACCESS - C & 0.213465 & & & \\
\hline _FIDELITY - C & 0.178544 & & & \\
\hline _FCMB-C & -0.013307 & & & \\
\hline - $\mathrm{FBN}-\mathrm{C}$ & 0.211026 & & & \\
\hline -GTB $-\mathrm{C}$ & -0.213413 & & & \\
\hline _UNION-C & 0.178219 & & & \\
\hline \multirow[t]{2}{*}{ ZZENITH-C } & 0.313864 & & & \\
\hline & - & & & \\
\hline _UNITY_-C & 1.269928 & & & \\
\hline - WEMA-C & 0.118827 & & & \\
\hline _STERLING-C & 0.212415 & & & \\
\hline ECO $-\mathrm{C}$ & 1.200284 & & & \\
\hline _STANBIC & & & & \\
\hline $\mathrm{IBTC}^{-}-\mathrm{C}$ & 1.122256 & & & \\
\hline
\end{tabular}

Effects Specification

\begin{tabular}{lcc} 
& S.D. & Rho \\
\hline \hline Cross-section random & 0.128432 & 0.7653 \\
Idiosyncratic random & 1.420875 & 0.0481 \\
\hline \hline
\end{tabular}

Weighted Statistics

\begin{tabular}{llll}
\hline \hline R-squared & 0.511726 & Mean dependent var & 1.242318
\end{tabular}




\begin{tabular}{lrlr} 
Adjusted R-squared & 0.493564 & S.D. dependent var & 0.248362 \\
S.E. of regression & 0.423431 & Sum squared resid & 11.143992 \\
F-statistic & 3.610967 & Durbin-Watson stat & 1.931299 \\
Prob(F-statistic) & 0.040321 & & \\
\hline \hline & Unweighted Statistics & \\
\hline \hline & & & 10.11405 \\
R-squared & 0.502004 & Mean dependent var & 1.304974 \\
Sum squared resid & 92.1305 & Durbin-Watson stat & \\
\hline
\end{tabular}

\section{Source: E-View 10.0 Version}

\section{HAUSMAN TEST ROA}

Decision rule: Since the probability value is greater than 5\%, the null hypothesis will be accepted thereby rejecting the alternative hypothesis of choosing fixed effects as the consistent and unbiased estimator for the model.

Correlated Random Effects - Hausman Test

Pool: Untitled

Test cross-section random effects

\begin{tabular}{llrrr}
\hline \hline Test Summary & $\begin{array}{c}\text { Chi-Sq. } \\
\text { Statistic }\end{array}$ & Chi-Sq. d.f. & Prob. \\
\hline \hline Cross-section random & $=$ & 4.012011 & 3 & 0.1207 \\
\hline \hline
\end{tabular}

